\title{
The Global Compact on Refugees: How the Sauti/VOICE Project
} fits

Josephine Ngebeh

Chi-Chi Undie

Population Council

Joanina Karugaba

Follow this and additional works at: https://knowledgecommons.popcouncil.org/departments_sbsr-rh

Part of the Demography, Population, and Ecology Commons, Family, Life Course, and Society Commons, International Public Health Commons, Medicine and Health Commons, and the Migration Studies Commons How does access to this work benefit you? Let us know!

\section{Recommended Citation}

Ngebeh, Josephine, Chi-Chi Undie, and Joanina Karugaba. 2019. "The Global Compact on Refugees: How the Sauti/VOICE Project fits," Sauti/VOICE Program Brief no. 3. Nairobi: UNHCR EHAGL Africa Bureau and Population Council. 


\section{The Global Compact on Refugees: How the Sauti/VOICE Project Fits}

\section{Introduction}

How can stakeholders support refugees in the present day, unprecedented global refugee crisis? At least one way is by entering into a clearly-defined compact to do so.

Developed in 2018, the Global Compact on Refugees is a non-binding agreement among United Nations Member States and other relevant stakeholders, including international organizations. A symbol of political will, the Compact demonstrates the commitment of the international community to enhanced cooperation and solidarity with both refugees and their host communities.

The Global Compact on Refugees provides the international community with guidance for supporting present day refugee communities, characterized by large populations and protracted refugee situations. To share the burden and responsibility of supporting refugees globally, stakeholders (including regional, international, and civil society organizations) have been invited to participate in Compact efforts, and tools to share burdens and responsibilities have been outlined.

This program brief presents these tools, and illustrates how the Sauti/VOICE Project utilizes them.

\section{But First: What's the Sauti/VOICE Project About?}

The Sauti/VOICE Project harnesses a strategic partnership between the UNHCR East and Horn of Africa and Great Lakes (EHAGL) Africa Bureau, the Population Council, and the Council's network of partners (referred to the Africa Regional Sexual and Gender-Based Violence [SGBV] Network) to amplify existing SGBV responses. The Africa Regional SGBV Network is a coalition of implementing partners in East and Southern Africa that work collectively to develop and promote the utilization of evidence-based response models for addressing SGBV in low-resource settings in the region.

The VOICE Project works with the UNHCR EHAGL Africa Bureau to incorporate the Network's evidence-based approaches into regional SGBV programming for refugee populations. Innovative SGBV response models previously developed and tested by the Network are introduced and institutionalized within UNHCR operations, with the support of the Network partners who designed and pioneered implementation of the approaches. 
With its exclusive focus on SGBV on refugee settings, the VOICE Project is in direct alignment with the Global Compact on Refugees, which places an emphasis on the gender-related barriers, including SGBV, confronted by women and girls in refugee situations and promotes the adoption and implementation of policies and programs to empower women and girls in refugee and host communities.

While recognizing the importance of a women- and girlcentered approach, the Compact does not ignore men and boys and the need for addressing their concerns as

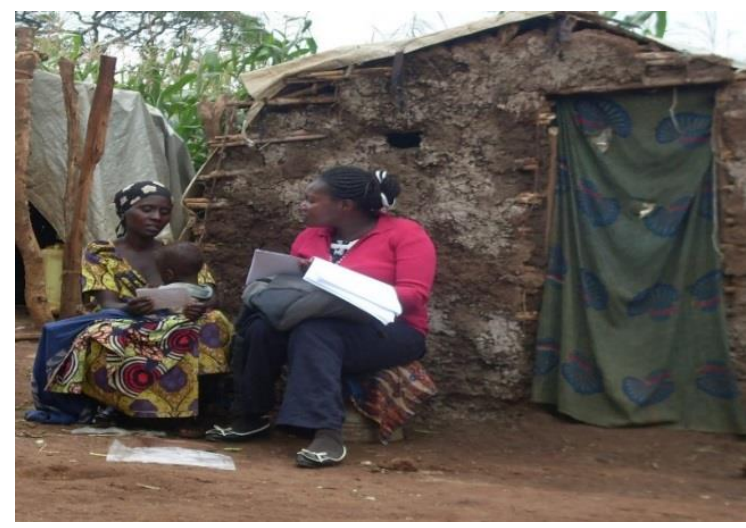
well. Similarly, the VOICE project maintains a focus on men and boys as well: all of its interventions are designed to directly respond to, or to meaningfully involve, men and boys alongside women and girls.

\section{Sauti/VOICE: A Perfect Fit for the Global Compact on Refugees}

Existing tools for effecting burden- and responsibility-sharing under the Global Compact include: a multistakeholder and partnership approach, funding and effective and efficient use of resources, along with data and evidence. The tools align with the Sauti/VOICE project's implementation approach.

\section{A Multi-Stakeholder and Partnership Approach}

Sauti/VOICE exemplifies a multi-stakeholder and partnership approach, founded upon a Technical Cooperation Agreement between the UNHCR EHAGL Africa Bureau and the Population Council in 2014, and brought into operation through the Africa Regional SGBV Network and UNHCR implementing partners, with the UNHCR EHAGL Africa Bureau playing a critical supportive and catalytic role.

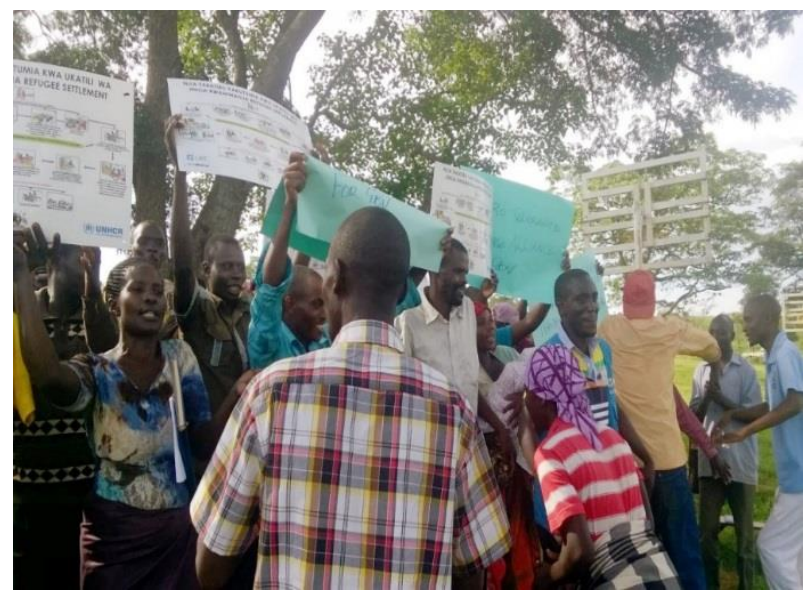

Under the Compact, civil society organizations are called upon to contribute to community needs and strengths assessments, and to capacity-building. Comprising multiple civil society organizations, the Africa Regional SGBV Network under the VOICE Project provides "South to South" technical support: southern-based CSOs help build the capacities of UNHCR implementing partners in the South to integrate proven SGBV responses within their operations, by training them in the implementation of specific SGBV models, carrying out intervention monitoring, and through continuous troubleshooting remotely and in-person. Additionally, South-South exchange and learning each occur through periodic regional learning meetings convened by the UNHCR EHAGL Africa Bureau and the Population Council, for UNHCR implementing partners and Network partners alike.

Refugees and host communities are meaningfully engaged in these activities. Both refugee and host community members are engaged in SGBV training sessions (as providers, for instance), and most interventions are situated in locations with access to both populations, ensuring that refugees and host community members alike are reached with SGBV intervention information, products, and services. 


\section{Funding and Effective and Efficient Use of Resources}

Successful implementation of the Global Compact on Refugees is dependent on funding, and one approach of the Compact is to engage non-traditional donors, including development actors. The Africa Regional SGBV Network provides financial support for UNHCR implementing partners' establishment of tested SGBV interventions, and for Network partners' technical assistance for this process. Seed funding is issued to UNHCR implementing partners for intervention implementation costs, or (in the case of costly interventions) to support key components of interventions. In addition, periodic regional convenings to foster South-South learning, exchange, and capacity-building between UNHCR implementing partners are financed by the VOICE Project.

\section{Data and evidence}

The SGBV response models implemented by UNHCR implementing partners through the VOICE Project are backed by data and evidence: Each has been tested under the Africa Regional SGBV Network and shown to be feasible and effective. While the VOICE Project focuses on implementation and scale-up (rather than on research), data and evidence are still a critical part of the project. With technical support from the Population Council, comparable monitoring data for every SGBV intervention are collected systematically over time. As recommended by the Compact, these data are helping determine intervention effects, identify predicaments and appropriate solutions, collate good practices and lessons, and inform SGBV program and policy development.

\section{Getting the Word Out}

To further popularize the Global Compact on Refugees and to garner additional support from development partners for the Compact's goals, the UNHCR EHAGL Africa Bureau and the Population Council co-convened a satellite session at the 2019 Sexual Violence Research Initiative (SVRI) Forum in Cape Town, South Africa on October 25, 2019. With over 6,000 members, SVRI is one of the largest global networks for advancing research on violence against women (VAW) and violence against children (VAC), and other forms of violence driven by gender inequality. SVRI brings together a diverse group of figures aiming to achieve a world free of VAW and VAC through improved practices and prevention programs informed by evidence, with a focus on low- and middle-income countries. The global SVRI network hosts the SVRI Forum (an international conference) every two years, convening SGBV experts from all over the world.

The UNHCR-Population Council satellite session at the 2019 SVRI Forum featured the Global Compact on Refugees and showcased the Sauti/VOICE project as an illustration of partnerships that the Compact aims to achieve. The financial contribution of the Sauti/VOICE project is being documented by the first Global Refugee Forum (in 2019) as a contribution for advancing the Compact's objectives, by broadening the base of support for refugees and host communities. 


\section{References}

UNHCR (2018). The global compact on refugees. Final draft (as at June 2018). https://reliefweb.int/report/world/global-compact-refugees-a7312-part-ii.

UNHCR (September 2018). The global compact on refugees: UNHCR quick guide. www.unhcr.org/ua/wpcontent/uploads/sites/38/2018/09/The-global-compact-on-refugees-UNHCR-quick-guide-ENG.pdf.

Since 2006, the Population Council-led Africa Regional SGBV Network has worked to build effective responses to SGBV in low-resource settings, focusing on those who have experienced violence, as well as on violence prevention. From 2018-2020, the network is collaborating with the UNHCR EHAGL Africa Bureau in Nairobi, Kenya, to address the needs of survivors in refugee settings in the East, Horn, and Great Lakes Regions of Africa through the ViOlence Response and Prevention through Information, Communication, and Education (VOICE) project. 'Voice' is translated as 'Sauti' in Kiswahili, and represents the project's emphasis on amplifying the voices of SGBV survivors and the efforts of the network's civil society organizations that work with them, to broaden the reach of effective SGBV responses across the region.

(C) 2019 UNHCR EHAGL Africa Bureau and the Population Council, Inc.

Citation: Josephine Ngebeh, Chi-Chi Undie, Joanina Karugaba (2019). 'The Global Compact on Refugees: How the Sauti/VOICE Project Fits.' The Sauti/VOICE Program Brief Series, Brief No. 3. Nairobi, Kenya: UNHCR EHAGL Africa Bureau and Population Council.

\author{
UNHCR EHAGL Africa Bureau \\ Contact: \\ Josephine Ngebeh \\ UNHCR EHAGL Africa Bureau \\ APHRC Campus, Kitisuru \\ P. O. Box 43801-00100 \\ Nairobi, Kenya \\ ngebeh@unhcr.org
}

\author{
UNHCR Geneva Contact: \\ Joanina Karugaba \\ UNHCR Geneva \\ Case Postale 2500 \\ 1211 Genève 2 Depôt \\ Switzerland \\ karugaba@unhcr.org
}

\author{
Africa Regional SGBV \\ Network Contact: \\ Chi-Chi Undie \\ Population Council \\ Avenue 5, Rose Avenue \\ Hurlingham \\ P. O. Box 17643-00500 \\ Nairobi, Kenya \\ cundie@popcouncil.org
}

